\title{
1 The Laxford Shear Zone: an end-Archaean terrane \\ 2 boundary?
}

3 K M Goodenough ${ }^{1, *}$; R G Park ${ }^{2}$; M Krabbendam ${ }^{1}$; J S Myers ${ }^{3}$; J Wheeler ${ }^{4}$; S C

4 Loughlin $^{1}$; Q G Crowley ${ }^{5,10}$; C R L Friend ${ }^{6}$; A Beach ${ }^{7}$; P D Kinny ${ }^{8}$ and R H Graham ${ }^{9}$.

5 1: British Geological Survey, West Mains Road, Edinburgh EH9 3LA, UK.

$6 \quad$ (* Corresponding author: kmgo@bgs.ac.uk)

7 2: 12 Provost Ferguson Drive, Tain, Ross-shire IV19 1RE, UK

8 3: 77 Falls Road, Lesmurdie, WA 6076, Australia

9 4: Department of Earth and Ocean Sciences, Liverpool University, Liverpool

10 L69 3GP, UK

11 5: NERC Isotope Geosciences Laboratory, Keyworth, Nottingham, NG12 5GG, UK

12 6: 45, Stanway Road, Risinghurst, Headington, Oxford, OX3 8HU

13 7: Exploration Outcomes, 1 Huntly Gardens, Glasgow, G12 9AS

14 8: Department of Applied Geology, Curtin University of Technology, 15 GPO Box U1987 Perth 6845, Western Australia

16 9: Hess, Level 9, Adelphi Building, London WC2N 6AG, UK

17 10: Department of Geology, Trinity College, Dublin 2, Ireland 18

Text 7,815 words; References 1,700 words; 7 figures; 1 table Abbreviated title: The Laxford Shear Zone 


\section{Abstract}

23 The Lewisian Gneiss Complex of north-western Scotland consists of Archaean 24 gneisses, variably reworked during the Proterozoic. It can be divided into three districts - a central granulite-facies district between districts of amphibolite-facies gneiss to the north and south. Recent work has interpreted these districts in terms of separate terranes, initiating a controversy that has implications for how Precambrian rocks are understood worldwide. The northern district of the Lewisian Gneiss Complex (the Rhiconich terrane) is separated from the central district (the Assynt terrane) by a broad ductile shear zone known as the Laxford Shear Zone.

31 This paper reviews the geology of the Laxford Shear Zone, clarifying field 32 relationships and discussing other evidence, to consider whether or not it does indeed represent a terrane boundary. A detailed review of field, geochemical and geochronological evidence supports the recognition of the separate Assynt and Rhiconich terranes. Mafic dykes (the Scourie Dyke Swarm) and granitoids, of

36 Palaeoproterozoic age, occur on both sides of the Laxford Shear Zone and thus the

37 terranes were most probably juxtaposed during the late Archaean to early

38 Palaeoproterozoic Inverian event. Subsequently, the less-competent, more-hydrous

39 amphibolite-facies gneisses of the Rhiconich terrane were affected by later

40 Palaeoproterozoic (Laxfordian) deformation and partial melting, to a greater extent

41 than the more-competent granulite-facies gneisses of the Assynt terrane. [end of 42 abstract] 
44 The Lewisian Gneiss Complex of north-western Scotland is one of the world's most 45 intensively studied regions of high-grade Precambrian gneisses, yet it continues to provide fruitful ground for new research. It crops out on the islands of the Outer Hebrides and also in a $140 \mathrm{~km}$-long strip along the north-west coast of the Scottish mainland, where it forms part of the foreland to the Caledonian orogen (Figure 1). The main outcrop is limited to the east by the Moine Thrust, although inliers of 'Lewisianoid' gneiss occur to the east of this major structure. The Lewisian gneisses form part of a now-disrupted Precambrian region in the North Atlantic, which also includes basement rocks in North America, Greenland and Scandinavia. The essential elements of the Lewisian Gneiss Complex were identified a century ago by the authors of the classic Geological Survey Memoir on the Northwest Highlands 55 (Peach et al., 1907). They recognised that the complex consists largely of metamorphosed plutonic igneous rocks, with relatively minor metasedimentary and metavolcanic units, cut by a variety of less-deformed igneous intrusions. They also divided the mainland Lewisian into three districts, northern, central and southern; the central district consisted largely of pyroxene-bearing gneiss (now recognised as granulite facies), whereas more strongly deformed hornblende- and biotite-bearing gneisses (amphibolite facies) cropped out to the north and south.

62 The main events within the Lewisian Gneiss Complex were later identified by Sutton 63 and Watson (1951), who recognised two major episodes of metamorphism and deformation, the 'Scourian' and 'Laxfordian' events, temporally separated by intrusion of an extensive dyke swarm known as the Scourie Dyke Swarm. A third, amphibolite-facies event, younger than the Scourian but pre-dating the Scourie Dykes, was recognised by Evans (1965) and termed the 'Inverian'. The 'Scourian' event was later renamed 'Badcallian’ (Park, 1970) and more tightly defined as a period of early granulite-facies metamorphism, which has to date only been recognised in the central 70 district of the Lewisian Gneiss Complex.

71 Over the last hundred years, the Lewisian Gneiss Complex has provided a natural 72 laboratory for studies into many aspects of basement geology (Park et al. 2002;

73 Wheeler et al. this volume). Major crustal-scale shear zones within the Lewisian 74 gneisses have been studied in detail, and provide large-scale examples of the type of 
shear zones described and analysed by the classic work of Ramsay and Graham (1970). Isotopic dating techniques were first harnessed for research into the history of the complex by Giletti et al. (1961) and have continued to provide crucial information as techniques - and the application of these techniques to high-grade metamorphic terranes - have been refined (see summary in Kinny et al., 2005).

Most recently, geochronological data have been used to identify crustal blocks with different histories within the Lewisian Gneiss Complex, and it has been proposed that these represent separate terranes that were assembled along major shear zones (Friend and Kinny, 2001; Kinny et al., 2005). The details of this model remain rather controversial, and a simpler version - in which two main terranes collided but were then divided into blocks by strike-slip movement - has also been proposed (Park, 2005). Overall, though, the idea that the Lewisian Gneiss Complex does not represent a contiguous block of Archaean crust is becoming more widely accepted. It is clear that the terrane model can usefully be tested by detailed investigations of the 'terranebounding' shear zones (Mason and Brewer, 2005).

One of the strongest candidates for a terrane-bounding shear zone is the Laxford Shear Zone, which separates the amphibolite-facies gneisses of the 'northern district' from the granulite-facies gneisses of the 'central district'. Following Coward and Park (1987), the Laxford Shear Zone is here defined as the broad ( $8 \mathrm{~km})$ zone of Inverian and Laxfordian ductile shear that extends along the southern shore of Loch Laxford and continues along the northern side of Ben Stack (Figures 2a, b). During the 'Continental Tectonics and Mountain Building' conference in Ullapool in May 2007, the authors of this paper engaged in two days of vigorous scientific discussion about the age and type of movements along that shear zone. The conclusions and further questions from that debate are presented here. This paper concentrates on reviewing previous work, clarifying the field relationships, and describing a consensus that has been reached by all the authors on the nature of the Laxford Shear Zone. Many disparate views on other aspects of the Lewisian exist within the author team, and these cannot all be addressed here. 


\section{Previous work on the Laxford Shear Zone}

106 The Lewisian gneisses of the Laxford area were first mapped by the Geological

107 Survey towards the end of the nineteenth century (Peach et al., 1892) and described in 108 the North-west Highlands Memoir (Peach et al., 1907). The surveyors recognised that 109 Loch Laxford lay roughly along a zone that separated biotite- and hornblende-bearing 110 gneisses of the 'northern district' from pyroxene-bearing gneisses of the 'central 111 district' of the Lewisian Gneiss Complex. They described the rocks of the northern 112 district as containing mafic layers that could be deformed dykes 'of the Scourie type', 113 and abundant granites and pegmatites that cross-cut all the other rock-types. They also 114 noted 'it is probable that all the granite dykes were not intruded at the same time'. In 115 the Loch Laxford area, they identified three WNW-ESE-trending belts in the 116 Lewisian gneisses:

117 1) A north-eastern belt in which hornblende- and biotite-bearing gneisses are cut 118 by intrusions of granite and pegmatite that 'probably exceed in bulk' the gneisses themselves.

2) A middle belt of hornblende- and biotite-bearing gneisses cut by mafic dykes, with abundant folds and shear zones. This belt was essentially what we would now describe as the Laxford Shear Zone.

3) A south-western belt of pyroxene-bearing gneisses in which the gently dipping gneissosity is cross-cut by undeformed mafic dykes (the Scourie Dyke Swarm).

126 The next major study of the area was that of Sutton and Watson (1951). They

127 considered that three major 'episodes' could be recognised in the history of the 128 gneisses around Loch Laxford: an early, 'Scourian' metamorphic event during which 129 granulite-facies pyroxene-bearing gneisses were formed; a period of intrusion of 130 dolerite dykes (the Scourie Dykes); and a second, 'Laxfordian' metamorphic event in 131 which the gneisses of the northern district were retrogressed to form hornblende- and 132 biotite-bearing gneisses (amphibolite facies metamorphism). Sutton and Watson 133 believed that the gneisses of the central and northern districts shared the same early 134 history, and were only distinguished by the later effects of the Laxfordian event. They 135 divided the Loch Laxford area into five zones (Figure 2b) and suggested that the 
136 variations across the zones were controlled by an episode of deformation, 'producing structures with a north-west to south-east trend' and a front of migmatisation. The five zones are (from SW to NE):

1) The Scourie zone, in which Laxfordian movement and metamorphism have only had a local effect on the 'Scourian complex'. This equates to the southwestern belt of the 1907 Memoir. Sutton and Watson (1962) suggested that the north-eastern boundary of this zone should be taken as the 'local Laxfordian front', and thus that all the gneisses to the north had undergone retrogression and metasomatism during the Laxfordian event.

2) The Claisfearn zone, consisting of flaggy gneisses with a steep southwestward dip, and 'numerous shear-belts'.

3) The Foindle zone, also with steep south-westward dips, and incorporating a thick band of mafic rocks (Figure 2a). Units of brown-weathering, schistose biotite-bearing gneisses were recognised and were considered to have formed through metasomatism of the mafic rocks. Shear belts were described as being 'entirely confined to the basic bodies' over much of this zone, and granite and pegmatite veins were considered to 'dwindle' southwards across the zone. The Claisfearn and Foindle zones together represent the middle belt of the 1907 Memoir.

4) The Badnabay zone, in which a large number of 'concordant sheets of granitegneiss' appear and 'there are no shear-belts'; the main foliation in this area was considered to equate to the second foliation formed in the shear belts to the south.

5) The Laxford zone, 'thickly veined with granites and pegmatites' and with no second foliation. The Badnabay and Laxford zones together equate to the north-eastern belt of the 1907 Memoir.

An alternative theory was proposed by Bowes (1962), who was the first to suggest that the rocks of the northern district had been tectonically juxtaposed with those of the central district during the Laxfordian event. Lambert and Holland (1972) defined the boundary between the two districts as the Ben Stack line, equivalent to the boundary between the Foindle and Badnabay zones of Sutton and Watson (1951) (Figure 2b). Following the identification of the pre-Scourie Dyke Inverian event in the 
168

169

170

171

172

173

174

175

176

177

178

179

180

181

182

183

184

185

186

187

188

189

190

191

192

193

194

195

196

197

198

199

200

central district (Evans, 1965), Holland (1966) noted that the area around Loch

Laxford also showed the effect of two successive amphibolite-facies metamorphic events (the pre-Scourie Dyke Inverian and post-dyke Laxfordian). Rb-Sr and K-Ar dating of gneisses placed the age of the Laxfordian event at Laxford Bridge as between c. 1850 and 1750 Ma (Lambert and Holland, 1972).

Geochemical studies of the Lewisian gneisses (Holland and Lambert, 1973; Sheraton et al., 1973) indicated that, on average, the gneisses to the north of the 'Ben Stack line' are rather richer in $\mathrm{K}_{2} \mathrm{O}, \mathrm{Rb}$, Th, $\mathrm{U}$ and $\mathrm{SiO}_{2}$ than those to the south. This evidence supported the theory of Bowes (1962) that the northern district gneisses did not represent retrogressed equivalents of the granulite facies gneisses of the central district, and that the Laxford Shear Zone represented a major structure along which two separate crustal blocks were juxtaposed.

Beach et al. (1974) formalised the term 'Laxford Front', which was defined as the southern limit of migmatites and Laxfordian granite sheets. This limit is approximately equivalent to the Ben Stack Line, but is difficult to place in the field, since scattered Laxfordian granite sheets do occur to the south of the area of migmatitic gneisses (Peach et al., 1907). Beach et al. (1974) studied the structural evolution of the Loch Laxford area, and recognised three significant deformation phases in the Laxford area, one pre-Scourie Dyke intrusion and two post-dyke. They mapped and described pre-Scourie Dyke folds but did not directly correlate their structures with the Inverian event, as defined near Lochinver by Evans (1965). They stated that 'there was negligible vertical displacement' on the Laxford Shear Zone during this first phase of deformation, but described post-Scourie Dyke shear zones with an oblique sinistral and north-up sense of movement. Structures formed in the third deformation phase were only recognised north of Laxford Bridge.

Davies (1974) followed suggestions made by Beach et al. (1974) in interpreting the brown-weathering, schistose biotite-bearing gneisses ('brown schists') of the Foindle zone as metamorphosed supracrustal rocks. He presented a detailed map of this zone and suggested that the supracrustal rocks lay on top of, and were infolded with, a layered, mafic igneous sheet. Davies (1976) presented evidence that the folding of this supracrustal/mafic igneous complex occurred before the end of the early granulitefacies metamorphism in the central district, and thus proposed that the belt of supracrustal rocks originated as a distinctive structure during the Archaean. Okeke et 
201 al. (1983) studied the chemistry of the brown biotite-bearing gneisses, and confirmed

202

203

204

205

206

207

208

209

210

211

212

213

214

215

216

217

218

219

220

221

222

223

224

225

226

227

228

229

230

231

232

233

that they represented a metasedimentary sequence of pelitic, semi-pelitic and psammitic gneisses. Recent detrital zircon dating indicates that the metasedimentary rocks were most probably derived from central district gneisses (Love, 2004). It has been suggested that this association of mafic and ultramafic rocks with metasedimentary rocks could represent a marginal ocean-floor assemblage, tectonically accreted to the continental margin (Park and Tarney, 1987).

Coward and Park (1987) and Coward (1990) re-investigated the structures of the Laxford area. Coward (1990) stated that 'the southern margin of Laxfordian deformation.... has the form of a large scale ductile shear zone, and is often termed the Laxford Front'. This shear zone was described as striking NW-SE, and $\sim 8 \mathrm{~km}$ in width, with heterogeneous deformation throughout. Coward (1990) recognised that pervasive Laxfordian deformation had occurred in a zone to the south of Laxford Bridge (the Badnabay zone) whereas further to the south (in the Claisfearn and Foindle zones) discrete Laxfordian shears are superimposed on Inverian deformation. Coward and Park (1987) suggested that the granulite-facies gneisses of the central region had been thrust over the amphibolite-facies gneisses to the north during the Inverian. The granulite-facies gneisses were then displaced back down toward the south during early Laxfordian deformation. A later Laxfordian movement, following granite emplacement, was described as having a south-up, dextral shear sense.

In the late 1980s, a sea-change began to occur in the way in which the Lewisian gneisses were investigated. Whitehouse (1989) used Sm-Nd isotopic data to suggest that the crust of the different 'districts' within the Lewisian Gneiss Complex might have formed at different times. Following on from this, modern isotopic techniques particularly U-Pb dating of zircons - were used to date events in the Lewisian Complex far more precisely than had hitherto been possible. Corfu et al. (1994) and Friend and Kinny (1995) presented U-Pb zircon and titanite data for gneisses in the central district immediately to the south of the Laxford Shear Zone. Differing techniques were utilised by these authors; Corfu et al. (1994) analysed whole grains or fragments of grains by conventional isotope dilution (ID-TIMS), whereas Friend and Kinny (1995) carried out in situ analysis using a high-resolution ion microprobe (SIMS). Both groups of authors recognised the complexity of the zircons in their samples, and different events affecting the zircons were recognised through the use of 
234 the differing techniques. The use of SIMS allowed Friend and Kinny (1995) to date

235 the oldest zircon cores, giving an age for the tonalitic gneiss protoliths of c. 2960 Ma.

236 The data in both studies were interpreted to show that the gneisses were

237 metamorphosed to high grade at 2490-2480 Ma, with a later metamorphic phase at

238 c.1750 Ma. However, an earlier high-grade metamorphic event at c. 2710 to $2760 \mathrm{Ma}$,

239 which was recognised by Corfu et al. (1994) and Zhu et al. (1997), was not resolvable

240 from the data of Friend and Kinny (1995). This has led to ongoing debate over the

241 absolute ages of the Badcallian and Inverian events (Corfu, 2007; Friend et al., 2007),

242 which is largely focused upon the reconciliation of differences between data sets

243 obtained by the different analytical techniques, and on the geological interpretation of

244 complex internal zonation and age patterns among zircon samples.

245 Kinny and Friend (1997) presented further U-Pb (SIMS) zircon and titanite data

246 which showed that the gneisses to the north of the Laxford Shear Zone had a

247 markedly different history to those of the central district. Gneisses of the northern

248 district were shown to have protolith ages of 2800-2840 Ma with evidence for later

249 dioritic intrusions at c. $2680 \mathrm{Ma}$, but no evidence was found for early high-grade

250 metamorphism. Isotopic evidence for Laxfordian reworking at c. $1750 \mathrm{Ma}$ and c.

2511670 Ma has been found in both districts (Kinny and Friend, 1997; Corfu et al.,

252 1994).

253 This work thus led to the suggestion that the Laxford Shear Zone represented the

254 boundary between two distinct crustal blocks, which were tectonically juxtaposed

255 between $2480 \mathrm{Ma}$ and $1750 \mathrm{Ma}$ (Kinny and Friend, 1997). On the basis of these new

256 dates, it has been proposed that the 'northern district' of Peach et al. (1907) should be

257 re-named the Rhiconich terrane, and that the northern part of the 'central district'

258 should be termed the Assynt terrane (Friend and Kinny, 2001; Kinny et al., 2005). For

259 ease of discussion, these names will be used henceforward in this paper - although

260 this should not be taken to imply complete acceptance of the terrane model at this

261 stage.

262 Subsequently, Friend and Kinny (2001) dated a granite sheet from the north side of

263 Loch Laxford at c.1855 Ma. They believed that these granite sheets only occur in the

264 Rhiconich terrane and thus stated that the two crustal blocks were juxtaposed between

$2651855 \mathrm{Ma}$ and 1750 Ma. A sample of gneiss from the 'Badnabay zone' of Sutton and

266 Watson produced a protolith age of c.2760 Ma, which was taken to indicate that this 
zone belonged to the Rhiconich terrane (Friend and Kinny, 2001). The boundary

268 between the two terranes was described as 'the highly strained boundary between the

269 Badnabay and Foindle zones' (Friend and Kinny, 2001) and this boundary was

270 described as the Laxford shear zone (Kinny et al., 2005). This is somewhat different

271 from the Laxfordian front of Sutton and Watson (1962), which represented the

272 southern limit of Laxfordian reworking and was taken at the southern margin of the

273 Claisfearn zone. As discussed above, we follow Coward and Park (1987) in defining

274 the Laxford Shear Zone as the broad, NW-SE zone of intense, ductile, Inverian and

275 Laxfordian shear that runs along the southern side of Loch Laxford (Figure 2b), and

276 encompasses the Badnabay, Foindle and Claisfearn zones of Sutton and Watson

277 (1951). Within the Laxford Shear Zone, the true boundary between rocks of the

278 Assynt and Rhiconich terranes is very difficult to place on the ground, as discussed in

279 the next section.

280

281 Field relationships and structure

\section{The Assynt terrane south of the Laxford Shear Zone}

283 The typical gneisses of the Assynt terrane are chiefly TTG (tonalite - trondhjemite -

284 granodiorite), granulite-facies gneisses, commonly grey in colour and well-banded on 285 the scale of a few centimetres (Peach et al., 1907). Enclosed within the grey gneisses 286 are mafic to ultramafic enclaves, the largest of which approach a kilometre in size.

287 Many of these enclaves represent low-strain zones and in some cases relict igneous 288 textures such as cumulate layering can be identified (Davies, 1974), although the 289 mineral assemblages are metamorphic (e.g. two pyroxenes + plagioclase + garnet in 290 the mafic rocks). Gneisses of metasedimentary origin are also found at a few 291 localities, notably on the north side of Scourie Bay (Okeke et al., 1983) and further 292 south at Stoer (Cartwright et al., 1985). These are quartzofeldspathic gneisses with 293 abundant garnet and biotite; kyanite, sillimanite, staurolite and corundum have been 294 recorded. Granulite-facies assemblages are locally preserved within the grey gneisses, 295 the mafic-ultramafic bodies, and the metasedimentary gneisses, although partial 296 retrogression to amphibolite-facies assemblages is common throughout the Assynt 297 terrane, and pervasive retrogression has occurred in discrete areas of later reworking. 
298 The gneisses are cut by Scourie Dykes, which are relatively undeformed, except

299 where they are cross-cut by Laxfordian shear zones.

300 The dominant early structure in the northern part of the Assynt terrane is a gently to

301 moderately west- or north-west-dipping gneissose layering (Beach et al., 1974),

302 which encloses rare intrafolial folds of a pre-existing foliation (e.g. Sheraton et al.,

303 1973). This gneissose layering is the result of high to very high strain as evidenced by

304 abundant pods, lenses and thin layers of mafic material that appear to have been

305 extended and thinned parallel to it, and is generally considered to be associated with

306 the Badcallian event (Park, 1970). A poorly-preserved weak grain-aggregate shape

307 lineation generally plunges towards the west or north-west.

308 Within the Assynt terrane, the gneisses are cut by a number of discrete shear zones.

309 The Canisp and Stoer shear zones are major, kilometre-wide steep zones of intense

310 ductile deformation and amphibolite-facies retrogression. These major shear zones are

311 considered to have formed in the Inverian and reactivated in the Laxfordian (Attfield,

312 1987; Coward and Park, 1987). Smaller-scale Laxfordian shear zones, a few metres to

313 tens of metres in thickness, are common across the Assynt terrane. These Laxfordian

314 shear zones increase in number northwards, into the Scourie zone of Sutton and

315 Watson (1951). In this zone, the gneissose layering is affected by local open folds and

316 by metre-scale monoclinal folds with thinned short limbs (shear zones) that are

317 assigned to the Inverian (Evans 1965, Evans \& Lambert 1974).

\section{The Laxford Shear Zone}

319 The Laxford Shear Zone (LSZ) can be divided into southern, central and northern 320 sectors that essentially correspond to the Claisfearn, Foindle and Badnabay zones of

321 Sutton and Watson (1951) (Figure 2b). The rocks within the LSZ are distinguished

322 from those to the south both by the incoming of intense, pervasive ductile

323 deformation, and by the ubiquitous presence of amphibolite-facies assemblages. The

324 rock-types found in the southern and central parts of the LSZ (the Claisfearn and

325 Foindle zones) include some evidence for relict granulite-facies assemblages (Davies,

326 1974) and so are considered to belong to the Assynt terrane, whereas the northern part

327 (the Badnabay zone) largely belongs to the Rhiconich terrane (Kinny et al. 2005).

328 The southern and central parts of the Laxford Shear Zone 
329 Within the southern part of the LSZ (the Claisfearn zone), the main foliation in the 330 gneisses trends uniformly WNW-ESE, dips steeply $\left(50-70^{\circ}\right)$ to the south-west, and is 331 axial-planar to occasional folds of the earlier gneissose banding. The foliation is cut 332 by several steep NW-SE-trending Scourie Dykes (Figure 3), and the discordant 333 relationships can be seen at many localities (e.g, around Tarbet; Beach, 1978). This 334 foliation is therefore considered to be Inverian, resulting from the thinning, steepening 335 and transposition of the original Badcallian gneissose banding into a broad Inverian 336 shear zone. In places, a weak to moderately strong mineral lineation plunges to the 337 south-east. Together with the reported antiformal bending of the earlier foliation into 338 the major Inverian shear zone, this suggests that the direction of movement on this 339 shear zone was south-side-up and oblique dextral (Coward and Park, 1987). Larger340 scale Inverian folds, also cross-cut by the dykes, were mapped and described by 341 Beach et al. (1974) (Figure 3).

342 The central part of the LSZ (the Foindle zone) contains a major belt of 343 metamorphosed mafic and ultramafic rocks, some garnetiferous, extending south-east 344 from north of Tarbet as far as Ben Stack (Figure 2a; Davies 1974, 1976). These are 345 commonly associated, and locally interfolded, with brown-weathering, garnet-biotite 346 semipelitic gneisses. The mafic bodies range in size, from a few metres up to several 347 hundred metres in thickness, and are laterally continuous for many kilometres.

348 Significant variations in strain can be seen across the mafic-ultramafic belt: in low349 strain areas, the rocks show relict igneous textures such as cumulate layering (e.g. 350 north of Gorm Loch around NC 2150 4450; Davies, 1974) and granulite-facies 351 assemblages may be preserved, with some spectacular large garnet aggregates 352 (Davies, 1974); whilst in higher-strain areas amphibolite-facies mafic and 353 metasedimentary gneisses are finer-grained, strongly foliated and lineated, with 354 foliations dipping steeply south-west and mineral lineations plunging towards the 355 south-east. Most of these fabrics can be shown to be Inverian, since relatively 356 undeformed Scourie Dykes cut across the amphibolite/semipelite assemblage at a 357 number of locations (e.g. south of Badnabay around NC 2335 4425). Davies (1976) 358 showed that this assemblage had been folded prior to Scourie Dyke intrusion.

359 Within the southern and central parts of the LSZ described above, later Laxfordian 360 deformation takes the form of discrete, narrow (1 - $100 \mathrm{~m})$, steeply dipping shear 361 zones, which have displaced the Scourie Dykes and led to the development of a 
362 localised foliation (Beach, 1974). A hornblende grain shape lineation within these

363 zones plunges moderately south-east, approximately parallel to the earlier Inverian

364 lineation, but the sense of movement is changed to oblique, sinistral and north side up

365 (Beach et al. 1974). These Laxfordian shear zones only occupy a relatively small

366 proportion $(<10 \%)$ of the outcrop area, but the sum of movement associated with

367 them may be of the order of tens of kilometres (Coward, 1990; Beach, 1974). Away

368 from these narrow shear zones the overall Laxfordian strain in the southern and

369 central parts of the LSZ appears to be very low, although Laxfordian strain within the

370 gneisses is hard to distinguish from Inverian effects in areas where Scourie Dykes are

371 absent. Minor folding of dyke margins appears to be restricted to the Laxfordian shear

372 zones(Beach et al. 1974). There is no evidence throughout the south-central parts of

373 the LSZ for any large-scale Laxfordian folds.

374 The Scourie Dykes maintain their NW-SE trend throughout the southern and central

375 parts of the LSZ; although they are displaced by the discrete Laxfordian shear zones,

376 they show no tendency to rotate overall into a more WNW-ESE orientation parallel to

377 these shear zones. In the model suggested by Coward (1974) the Inverian shear zone

378 acts as an antithetic south-down shear zone which rotates in an anticlockwise fashion,

379 looking north-east, during the Laxfordian. Thus the south-down sinistral shear sense

380 exhibited by the steeply dipping Laxfordian shear zones where they cut the Scourie

381 Dykes is a response to horizontal north-directed shear (Figure 4).

382 In some places the Scourie Dykes deflect into and follow the zones of Inverian shear

383 for a short distance, or send small veins parallel to them (e.g. south of Tarbet at

384 NC1639 4854). These deviations from the normal trend of the dykes can often be

385 shown to be intrusive features and not due to later Laxfordian deformation, as first

386 deduced by Clough (in Peach et al. 1907; see also Park \& Cresswell 1972).

387 Within the central part of the LSZ, scattered biotite granite and granitic pegmatite

388 sheets up to $10 \mathrm{~m}$ thick cut across the mafic/ultramafic bodies, the semipelitic

389 gneisses, and the quartzofeldspathic gneisses (e.g. south of Badnabay at NC 2168

390 4574). Some of the granitoid sheets carry a weak Laxfordian fabric, but they clearly

391 cross-cut the dominant Inverian foliation (Figure 5). In some cases the granite sheets

392 are axial-planar to small-scale upright Laxfordian folds. The relationship between

393 these granite sheets and the discrete Laxfordian shear belts described above is unclear.

394 However, it is important to note that these granitic sheets cut rocks (such as the 
395 mafic/ultramafic gneisses and metasedimentary gneisses) that are generally agreed to

396 belong to the Assynt terrane, contrary to the suggestion of Friend and Kinny (2001)

397 that the granitic sheets occur only in the Rhiconich terrane.

398 The northern part of the Laxford Shear Zone

399 The northern part of the LSZ is equivalent to the Badnabay zone of Sutton and

400 Watson (1951) (Figure 2b). It is characterised by the presence of abundant sheets of

401 granite and granitic pegmatite, varying in thickness from 1 to $100 \mathrm{~m}$, which cut highly

402 strained gneisses (Figure 6). The thicker granites are weakly foliated and are mostly

403 concordant with the main foliation in the gneisses. This strong foliation dips steeply

404 towards the south-west, and is essentially indistinguishable from the Inverian foliation

405 in the southern and central parts of the LSZ. However, in the northern part of the LSZ

406 this main fabric has been identified as Laxfordian in age (Coward, 1990). This

407 conclusion is difficult to confirm due to the apparent absence of Scourie Dykes within

408 the northern part of the LSZ, although the closest Scourie Dykes do seem to be

409 strongly thinned (Peach et al., 1892; Figure 2a) - this indicates that at least some of

410 the deformation is Laxfordian, but it may have been superimposed upon significant

411 Inverian deformation.

412 Sutton and Watson (1951) defined the southern boundary of their Badnabay zone by

413 the incoming of abundant, weakly foliated granitic sheets (the Rubha Ruadh granites).

414 It is of course very difficult to draw a boundary along the southern side of the 'zone of

415 abundant granitic sheets' since the definition of 'abundant' is naturally subjective.

416 The most likely candidate for such a boundary would be the margin of a $\sim 50 \mathrm{~m}$ thick

417 granitic sheet, which forms steep cliffs on the northern slopes of Ben Stack, and

418 extends north-west as far as Badnabay, beyond which it divides into thinner sheets

419 that die out along strike (Figure 2a). The margin of this thick granitic sheet (and its

420 extensions to the west) is discordant with the trend of the main foliation (as noted by

421 Beach et al., 1974). Furthermore, as described above, a number of weakly foliated to

422 undeformed granite sheets up to $10 \mathrm{~m}$ thick occur to the south of this main granite

423 sheet.

424 The boundary between the Assynt and Rhiconich terranes, which is considered to lie

425 within the northern part of the LSZ, should separate banded tonalitic gneisses with

426 mafic, garnetiferous amphibolitic pods, from migmatitic granodioritic gneisses to the 
north. This boundary cannot be defined as a sharp line on the ground. Around Loch Stack, it is typically obscured by thick granite sheets, but to the west it can be traversed at a number of localities. There are some localities where the boundary can be placed to within around one hundred metres; for example, in the A894 road cuts close to Loch na Claise Fearna (NC 2044 4710), outcrops of mafic and ultramafic rocks with associated metasedimentary units rapidly give way northwards to migmatitic gneisses. However, in other places the boundary appears much more gradational on a scale of hundreds of metres, with the incoming of increasing amounts of granodioritic material to the north. On the south side of Loch Laxford, near Rubha Ruadh, abundant granitic sheets cut tonalitic gneisses with mafic to ultramafic lenses, which appear to belong to the Assynt terrane (Figure 6).

\section{The Rhiconich terrane north of the Laxford Shear Zone}

To the north of Loch Laxford and the Laxford River (Figure 2a), thick granitic sheets ( $>10 \mathrm{~m}$ ) are much less common, and the rocks are chiefly migmatitic amphibolitefacies gneisses with an extensive, anastomosing network of thinner sheets of granite and pegmatitic granite. The migmatitic gneisses of this area are grey to pink in colour and broadly granodioritic in composition. Small mafic enclaves occur locally, but rarely exceed $1 \mathrm{~m}$ in size; large garnet amphibolite bodies are not found. At the northern margin of the LSZ the main (Laxfordian) foliation dips steeply to the southwest in parallel with that within the LSZ (Figure 3). To the north, the foliation becomes less steep and gradually bends over to a sub-horizontal attitude at the crest of the Rhiconich antiform. The foliation is associated with a moderately south-eastplunging lineation similar to that in the LSZ.

In some places, the granitic sheets make up $>50 \%$ of the outcrop area. They are commonly irregular in shape, cross-cut the gneissose layering, and are themselves weakly foliated to undeformed. Locally, foliation-parallel migmatitic leucosomes can be traced into cross-cutting pegmatitic sheets (e.g. in road-cuts near Rhiconich at NC 2464 5191), indicating that these intrusive sheets are largely formed by partial melting of local crust. This was apparently confirmed by $\mathrm{Rb}-\mathrm{Sr}$ and $\mathrm{Pb}$ isotopic data for granites north of the LSZ which indicated crustal sources (Taylor et al., 1984). More recent experimental work (Watkins et al., 2007) has suggested that the composition of the granitic sheets could not be produced by the melting of local crustal sources in the Rhiconich terrane - although the parent gneisses used in their experiments had 
460 unusually low $\mathrm{K}_{2} \mathrm{O} / \mathrm{Na}_{2} \mathrm{O}$ ratios when compared with the average compositions for 461 gneisses north of the LSZ given by Holland and Lambert (1973). The origin of the 462 granitic sheets in the Rhiconich terrane is therefore uncertain.

463 Amphibolite sheets that are interpreted as part of the Scourie Dyke Swarm are 464 common in the region north of Loch Laxford. They are pervasively deformed, with a 465 strong Laxfordian foliation, and are sub-parallel to the main gneissose layering, 466 although local low-angle discordances indicate that the dykes post-date the 467 gneissosity as in the Assynt terrane. The dykes, together with the gneissose layering, 468 are affected by a set of north-east-verging asymmetric overfolds on a scale of metres 469 (Beach et al., 1974). The granite and pegmatite sheets cut both the Laxfordian 470 foliation in the dykes and the overfolds, being in some cases parallel to the fold axial 471 planes.

472 Correlation of structures across the Laxford Shear Zone depends on the identification 473 of the dykes in the Rhiconich terrane as part of the Scourie Dyke Swarm. If this 474 correlation is accepted, the pre-dyke foliation in the north could be correlated with the 475 Inverian further south. There are however, significant differences in the post-dyke 476 (Laxfordian) structure across the LSZ, the most obvious being the much greater 477 intensity of Laxfordian deformation and folding in the north. These differences in 478 deformation are most simply explained by the competence differences between the 479 480 granulite-facies Assynt terrane and the more ductile gneisses of the Rhiconich terrane; more competent than hydrous amphibolite-facies rocks (e.g. Wilks and Carter, 1990). The Inverian shear zone provided a convenient boundary along which the high Laxfordian strain was focused into the more ductile rocks of the Rhiconich terrane.

\section{Geochemical characteristics of the Assynt and Rhiconich terranes}

The Laxford Shear Zone separates two areas with very different geochemical characteristics; the gneisses of the Assynt terrane are conspicuously depleted in K, $\mathrm{Rb}$, Th and $\mathrm{U}$, and have very high $\mathrm{K} / \mathrm{Rb}$ ratios, when compared to the gneisses of the Rhiconich terrane (Sheraton et al., 1973; Holland and Lambert, 1973). The origin of these differences has been the subject of extensive debate, the conclusions of which have important implications for the terrane model. 
491 The characteristic alkali element depletion in the Assynt terrane gneisses has been

492

493

494

495

496

497

498

499

500

501

502

503

504

505

506

507

508

509

510

511

512

513

514

515

516

517

518

519

520

521

522

523

widely attributed to removal of these elements by $\mathrm{CO}_{2}$-rich fluids during granulitefacies metamorphism (Sheraton et al., 1973; Hamilton et al., 1979; Weaver and Tarney, 1981a), although it has also been suggested that the gneisses represent the residuum left after the removal of partial melts (Pride and Muecke, 1980; Cartwright and Barnicoat, 1987). However, Tarney and Weaver (1987) raised the possibility that the element depletions seen in the Assynt terrane could be a primary feature of the original igneous intrusions, related to the subduction-zone processes through which the original magmas were formed. This idea was supported by the work of Cartwright and Valley (1992) who used oxygen isotope data to show that large volumes of fluid did not pass through the gneisses of the Assynt terrane during granulite-facies metamorphism, whilst Rollinson (1994) provided arguments against partial melting. More recently, Rollinson (1996) and Rollinson and Tarney (2005) have argued that the geochemical features of the Assynt terrane are indeed primary igneous features, with the original magmas being derived from a subducting slab that has undergone incremental melting and early removal of the fluid-mobile elements.

Recent work has revived the older idea that the gneisses of the Rhiconich terrane were originally also depleted, but were metasomatically enriched in $\mathrm{K}, \mathrm{Rb}$, Th and $\mathrm{U}$, causing partial melting and migmatisation, during the Laxfordian (Sutton and Watson, 1951; Castro, 2004). Although the introduction of fluid may well have played some role in the Laxfordian migmatisation, it is likely that such metasomatism would have been localised along shear zones, and that it would be possible to find unmetasomatised regions that preserved a pre-Laxfordian composition. Examples of this process have been demonstrated in granulite facies gneisses in the Bergen Arcs (Austrheim, 1987). In the Rhiconich terrane, all the gneisses - even away from areas of intense deformation and migmatisation - have similar $\mathrm{K}, \mathrm{Rb}$, Th and $\mathrm{U}$ contents (Weaver and Tarney, 1981a).

It therefore appears most likely that the geochemical differences in the gneisses across the Laxford Shear Zone are a primary feature, due to distinctly different protolith geochemistries, rather than being related to metamorphic histories. The gneisses of the Assynt terrane were most probably formed from magmas derived by melting of a subducting slab (Rollinson and Tarney, 2005), whereas the chemistry of the Rhiconich gneisses is more like that of modern-day calc-alkaline igneous rocks, and 
524 the most likely origin for the magmas is in the mantle wedge above the subducting

525 slab. The geochemistry thus does indicate that there were differences in the process of

526 crust formation to the north and south of the Laxford Shear Zone (Rollinson, 1996).

527 As part of the recent BGS mapping of the area, Scourie Dykes from the Rhiconich

528 terrane were sampled and analysed for major and trace elements (Table 1). These data

529 can be compared with the geochemistry of the Scourie Dykes in the Assynt terrane,

530 which has been studied by Weaver and Tarney (1981b). There is considerable

531 geochemical variation within the Scourie Dykes of the Assynt terrane, and the

532 samples from the Rhiconich terrane lie within the same range. On multi-element plots

533 (Figure 7), all the dykes from both terranes are characterised by negative $\mathrm{Nb}$

534 anomalies, which have typically been considered to be a feature of the lithospheric

535 mantle source of the Scourie Dykes (Weaver and Tarney, 1981b). The Scourie Dykes

536 from within the Rhiconich terrane do typically have higher $\mathrm{K}$ and $\mathrm{Rb}$ contents than

537 those within the Assynt terrane, but this can almost certainly be attributed to

538 contamination of the magmas by the surrounding gneisses. Overall, the geochemical

539 data indicate that Scourie Dykes from both the Rhiconich and Assynt terranes are

540 likely to be part of the same dyke swarm.

541 Does the Laxford Shear Zone separate two distinct terranes?

542 The concept of separate terranes that have been accreted to form a now-contiguous

543 tectonic belt was developed in the North American Cordillera. Terranes were

544 described as blocks of crust that are 'characterised by internal homogeneity and

545 continuity of stratigraphy, tectonic style and history' with the boundaries between

546 terranes being 'fundamental discontinuities in stratigraphy' that separate 'totally

547 distinct temporal or physical rock sequences’ (Coney et al., 1980). Boundaries

548 between terranes were considered as 'faults that usually display complex structural

549 history'.

550 Several lines of evidence support the recognition of different terranes to the north and

551 south of the Laxford Shear Zone.

552 - Field and petrographical evidence clearly indicates different metamorphic

553 histories across the Laxford Shear Zone - in particular the existence of a

554 granulite-facies metamorphic event that affected the whole of the Assynt

555 terrane but for which there is no evidence in the Rhiconich terrane. 
- SIMS U-Pb zircon dating has showed that the protolith ages of gneisses in the Rhiconich terrane (2800 - $2840 \mathrm{Ma}$ ) are different from those in the Assynt terrane (2960 - $3030 \mathrm{Ma})$ (Kinny and Friend, 1997).

- A metamorphic event at c. 2490 Ma in the Assynt terrane (Corfu et al., 1994; Kinny and Friend, 1997) has not been identified in samples from the Rhiconich terrane.

- The gneisses of the Assynt terrane are strongly depleted in $\mathrm{K}, \mathrm{Rb}$, Th and $\mathrm{U}$, and have very high $\mathrm{K} / \mathrm{Rb}$ ratios, when compared to the gneisses of the Rhiconich terrane (Sheraton et al., 1973; Holland and Lambert, 1973). These geochemical differences are considered to be igneous rather than metamorphic (Rollinson and Tarney, 2005).

- The Laxford Shear Zone is a major structure with a complex structural history. As pointed out by Park (2005), it is possible for rocks with different protolith ages and geochemistries to occur within the same terrane, simply representing plutons intruded at different ages but adjacent to each other. However, in the example under discussion here, it is clear that the plutonic rocks to the north and south of the Laxford Shear Zone have undergone different metamorphic histories, before being juxtaposed along a major ductile shear zone. When considered together, the variation in protolith ages, metamorphic histories, and protolith geochemistry provide evidence that the Laxford Shear Zone separates two blocks of crust that are both temporally and physically distinct. In this respect, the LSZ satisfies the criteria laid out by Coney et al. (1980) for a terrane boundary. However, it must be noted that the relative position of these terranes, prior to their juxtaposition, has not been quantified.

\section{When were the two terranes juxtaposed?}

There is little doubt that the two terranes were separated at the time that granulitefacies metamorphism (the Badcallian event) took place in the Assynt terrane, since there is no field, petrographical or geochronological evidence for this event in the Rhiconich terrane. The absolute age of this event is uncertain (Corfu, 2007; Friend et al., 2007. However, a metamorphic event which occurred at c. 2490 Ma in the Assynt terrane (Corfu et al., 1994; Kinny and Friend, 1997) has not been identified in zircons from the Rhiconich terrane, and this may indicate that the two terranes were separate up to this point (Friend and Kinny, 2001). 
588 The first event that appears to be common to both terranes is the intrusion of the

589 Scourie Dykes. The Scourie Dykes in the Assynt terrane have been dated as c. 2000 -

5902400 Ma (Heaman and Tarney, 1989; Waters et al., 1990); no examples have been

591 dated from the Rhiconich terrane. As discussed above, the field relationships and

592 geochemistry of the dykes in the Rhiconich terrane are compatible with their being

593 part of the Scourie Dyke Swarm, and it is therefore possible that the two terranes were

594 juxtaposed by the time of Scourie Dyke intrusion. Unfortunately, no Scourie Dykes

595 can be traced that cut right across the Laxford Shear Zone; the early mapping

596 indicated that they are strongly thinned into the area of intense Laxfordian

597 deformation in the northern part of the LSZ (Peach et al., 1892).

598 In their development of a terrane model, Friend and Kinny (2001) made the

599 assumption that Laxfordian granite sheets (the 'Rubha Ruadh granites') only occur in

600 the Rhiconich terrane. On this basis, having dated one of these granite sheets at 1854

$601 \pm 13 \mathrm{Ma}$, they suggested that the terranes must have been juxtaposed following the

602 emplacement of the granites. However, as described above, further study of the field

603 relationships shows that some granite sheets cut mafic-ultramafic bodies and

604 metasedimentary gneisses that are generally agreed to be part of the Assynt terrane, as

605 originally recognised by Sutton and Watson (1951), and the granites therefore 'stitch'

606 the two terranes. No dates have yet been published for these granites within the

607 Assynt terrane, but on the basis of field relationships they appear likely to be related

608 to the Rubha Ruadh granites.

609 It has been shown that partial melting of Archaean granulite-facies tonalitic gneisses,

610 like those of the Assynt terrane, only produces very small amounts of magma (Castro,

611 2004). In contrast, it is likely that the gneisses of the Rhiconich terrane, with higher

612 amounts of the fusible, heat-producing elements and higher contents of hydrous

613 mineral phases, could produce significantly larger volumes of partial melt. Thus, we

614 suggest that partial melting and formation of granitic magmas occurred preferentially

615 on the north side of the Laxford Shear Zone, with only limited intrusion of granites on

616 the southern side. Similarly, later Laxfordian deformation was preferentially taken up

617 by the more ductile gneisses to the north. The heat source that caused the partial

618 melting is unknown, but it is possible that it may have been due to the introduction of

619 more primitive, mantle-derived magma into the base of the crust. However, the only

620 mafic magmatism known around that time is the South Harris Complex of the Outer 
621 Hebrides Lewisian, which was intruded at c. 1880-1890 Ma (Whitehouse and

622 Bridgwater, 2001; Mason et al., 2004), some time prior to the formation of the Rubha

623 Ruadh granites.

624 We have shown that the two terranes were certainly juxtaposed prior to c. 1854 Ma

625 granite intrusion, and probably prior to 2000-2400 Ma Scourie Dyke intrusion, but

626 clearly after the Badcallian granulite-facies metamorphism in Assynt. We therefore

627 suggest that the two terranes were brought together during the first and most

628 pervasive phase of deformation on the LSZ; the Inverian event. During this event,

629 deformation was focused along the terrane boundary as the granulite-facies gneisses

630 of the Assynt terrane were thrust over the gneisses of the Rhiconich terrane (Coward

631 and Park, 1987). It should be noted that the terms 'Badcallian' and 'Inverian' are used

632 here as they were originally defined; that is, as the granulite-facies and amphibolite-

633 facies events, respectively, that occurred prior to the intrusion of the Scourie Dyke

634 Swarm. The absolute age of these events continues to be the subject of a debate

635 (Corfu, 2007; Friend et al., 2007), which cannot be resolved by the evidence

636 presented here.

637 Conclusions

638 This reappraisal of the Laxford Shear Zone highlights the importance of integrating

639 field observations with geochronological and geochemical data in the development of

640 any geological model for high-grade gneiss areas. There is significant evidence to

641 show that the Assynt and Rhiconich terranes represent separate blocks of crust with

642 very differing histories: the geochemical data illustrate differences in their

643 petrogenesis, whilst geochronological, petrological and field data show that the

644 Assynt terrane has experienced a granulite-facies tectonic event that did not affect the

645 Rhiconich terrane.

646 These two separate terranes were juxtaposed along the major Laxford Shear Zone,

647 which was a locus for both Inverian and Laxfordian deformation. Reappraisal of the

648 field relations has indicated that Laxfordian granites occur across the Laxford Shear

649 Zone and thus it is likely that the terranes were juxtaposed prior to the Laxfordian

650 event. We therefore suggest that terrane juxtaposition occurred during the Inverian

651 event, the exact age of which is as yet uncertain (although it is likely that it occurred

652 relatively soon after the Archaean - Proterozoic boundary at c. $2500 \mathrm{Ma}$ ). The 
653 terrane-bounding shear zone was substantially reactivated during the Laxfordian, as a

654 site of both deformation and magmatism.

655 Many questions remain to be answered with reference to the formation of the Laxford

656 Shear Zone. How much movement was there along the LSZ in the Inverian, and what

657 exactly were the kinematics of shearing? Do the mafic-ultramafic and

658 metasedimentary rocks found within the LSZ represent a fragment of ocean floor that

659 once separated the terranes and that was then accreted to the continental margin, as

660 suggested by Park and Tarney (1987) - or were the two crustal blocks formed at a

661 distance from each other within the same continental mass, and subsequently moved

662 together? How can we harness the different available techniques to improve our

663 interpretation of the complex zircons found in the Lewisian gneisses, and thus reach a

664 consensus on the dates of the main events? What, indeed, is the absolute age of the

665 Inverian, and was this a time of more regional terrane amalgamation? What were the

666 tectonic processes that were operating at the end of the Archaean to bring these

667 terranes together? As ever, the rocks of the Lewisian Gneiss Complex remain a

668 fruitful subject for further research.

669

\section{Acknowledgements}

671 Rob Butler, Bob Holdsworth, Maarten Krabbendam, Rick Law and Rob Strachan

672 organised the conference in Ullapool that stimulated our discussions on the Laxford

673 Shear Zone. Randy Parrish, Martin Hand and John Mendum, as well as many other

674 participants of the Ullapool conference, are thanked for discussions in the field.

675 Editorial comments by Rob Strachan, constructive reviews by Hugh Rollinson and

676 Martin Whitehouse, and comments on an earlier version by Roger Key and Martin

677 Smith, were much appreciated. KMG, MK, QC and SCL publish with the permission

678 of the Executive Director of the Geological Survey.

679

680 
681

682

683

684

685

686

687

688

689

690

691

692

693

694

695

696

697

698

699

700

701

702

703

704

705

706

707

708

709

710

711

712

713

714

715

716

717

718

719

720

721

722

723

724

725

726

727

728

729

730

Attfield, P. 1987. The structural history of the Canisp Shear Zone. In: Park, R. G. and Tarney, J. (eds) Evolution of the Lewisian and comparable Precambrian highgrade terrains, Geological Society of London Special Publication 27, 165-173

Austrheim, H. 1987. Eclogitization of lower crustal granulites by fluid migration through shear zones. Earth and Planetary Science Letters, 81, 221-232.

Beach, A. 1978. The Scourie-Laxford Region (Lewisian). In: Barber, A. J., Beach, A., Park, R. G., Tarney, J. and Stewart, A. D. (eds) Geologists' Association Guide No. 21: The Lewisian and Torridonian rocks of North-West Scotland. The Geologists' Association, London.

Beach, A. 1974. The Measurement and Significance of Displacements on Laxfordian Shear Zones, North-West Scotland. Proceedings of the Geologists' Association, 85, 13-21.

Beach, A., Coward, M. P. and Graham, R. H. 1974. An interpretation of the structural evolution of the Laxford front. Scottish Journal of Geology, 9, 297-308.

Bowes 1962. Untitled discussion. Proceedings of the Geological Society of London, 1594, 28-30.

Cartwright, I., Fitches, W.R., O’Hara, M.J., Barnicoat, A.C., and O’Hara, S. 1985. Archaean supracrustal rocks from the Lewisian near Stoer, Sutherland. Scottish Journal of Geology 21, 187-196.

Cartwright, I. and Barnicoat, A. C. 1987. Petrology of Scourian supracrustal rocks and orthogneisses from Stoer, NW Scotland: implications for the geological evolution of the Lewisian complex. In: Park, R. G. and Tarney, J. (eds) Evolution of the Lewisian and comparable Precambrian high-grade terrains, Geological Society of London Special Publication 27, 93-108

Cartwright, I. and Valley, J. W. 1992. Oxygen-isotope geochemistry of the Scourian complex, northwest Scotland. Journal of the Geological Society of London, 149, 115-125.

Castro, A. 2004. The source of granites: inferences from the Lewisian complex. Scottish Journal of Geology, 40, 49-65

Corfu, F., Heaman, L. M. and Rogers, G. 1994. Polymetamorphic evolution of the Lewisian complex, NW Scotland, as recorded by U-Pb isotopic compositions of zircon, titanite and rutile. Contributions to Mineralogy and Petrology, 117, 215-228.

Corfu, F. 2007. Comment to paper: Timing of magmatism and metamorphism in the Gruinard Bay area of the Lewisian gneiss complex: comparison with the Assynt Terrane and implications for terrane accretion. Contributions to Mineralogy and Petrology, 153, 483-488.

Coney, P. J., Jones, D. L., and Monger, J. W. H. 1980. Cordilleran suspect terranes. Nature, 288, 329-333.

Coward, M. P. 1974. Flat lying structures within the Lewisian basement gneiss complex of NW Scotland. Proceedings of the Geologists' Association, 85, 459-472.

Coward, M. P. 1990. Shear zones at the Laxford front, NW Scotland and their significance in the interpretation of lower crustal structure. Journal of the Geological Society of London, 147, 279-286.

Coward, M. P. and Park, R. G. 1987. The role of mid-crustal shear zones in the Early Proterozoic evolution of the Lewisian. In: Park, R. G. and Tarney, J. (eds) Evolution of the Lewisian and comparable Precambrian high grade terrains. Geological Society of London Special Publication 27, 127-138.

Davies, F. B. 1974. A layered basic complex in the Lewisian, south of Loch Laxford, 
Sutherland. Journal of the Geological Society of London, 130, 279-284.

Davies, F. B. 1976. Early Scourian structures in the Scourie-Laxford region and their bearing on the evolution of the Laxford Front. Journal of the Geological Society of London, 132, 543-554.

Evans, C. R. 1965. Geochronology of the Lewisian basement near Lochinver, Sutherland. Nature, 207, 54-56.

Evans, C. R. and Lambert, R. S. J. 1974. The Lewisian of Lochinver: the type area for the Inverian metamorphism. Journal of the Geological Society of London, 130, 125-150

Friend, C. R. L. and Kinny, P. D. 1995. New evidence for protolith ages of Lewisian granulites, northwest Scotland. Geology, 23, 1027-1030.

Friend, C. R. L. and Kinny, P. D. 2001. A reappraisal of the Lewisian Gneiss Complex: geochronological evidence for its tectonic assembly from disparate terranes in the Proterozoic. Contributions to Mineralogy and Petrology, 142, 198-218.

Friend, C.R.L., Kinny, P.D. and Love, G.J. 2007. Timing of magmatism and metamorphism in the Gruinard Bay area of the Lewisian gneiss complex: comparison with the Assynt Terrane and implications for terrane accretion reply. Contributions to Mineralogy and Petrology, 153, 489-492.

Giletti, B. J., Moorbath, S. and Lambert, R. S. J. 1961. A geochronological study of the metamorphic complexes of the Scottish Highlands. Quarterly Journal of the Geological Society of London, 117, 233-264.

Hamilton, P. J., Evensen, N. M., O'Nions, R. K. and Tarney, J. 1979. Sm-Nd systematics of Lewisian gneisses: implications for the origin of granulites. Nature, 277, 25-28.

Heaman, L. and Tarney, J. 1989. U-Pb baddeleyite ages for the Scourie dyke swarm, Scotland: evidence for two distinct intrusion events. Nature, London, 340, 705-708.

Holland, J. G. 1966. Geochemical studies in the Lewisian. Unpublished Thesis, Oxford University

Holland, J. G. and Lambert, R. S. J. 1973. Comparative major element geochemistry of the Lewisian of the mainland of Scotland. In: Park, R. G. and Tarney, J. (eds) The early Precambrian of Scotland and related rocks of Greenland. University of Keele, Keele, 51-62.

Kinny, P. and Friend, C. 1997. U-Pb isotopic evidence for the accretion of different crustal blocks to form the Lewisian Complex of Northwest Scotland. Contributions to Mineralogy and Petrology, 129, 326-340.

Kinny, P. D., Friend, C. R. L. and Love, G.J. 2005. Proposal for a terrane-based nomenclature for the Lewisian Complex of NW Scotland. Journal of the Geological Society of London, 162, 175-186.

Lambert, R. S. J. and Holland, J. G. 1972. A geochronological study of the Lewisian from Loch Laxford to Durness, Sutherland, NW Scotland. Quarterly Journal of the Geological Society of London, 128, 3-19.

Love, G.J. 2004. The origins and accretionary development of the Lewisian Gneiss Complex of Northwest Scotland: constraints from in situ $\mathrm{U}-\mathrm{Pb}$ and $\mathrm{Hf}$ isotopic analysis of accessory minerals. Unpublished PhD Thesis, Curtin University of Technology.

Mason, A. J. and Brewer, T. S. 2005. A re-evaluation of a Laxfordian terrane boundary in the Lewisian Complex of South Harris, NW Scotland. Journal of the Geological Society of London, 162, 401-408. 
Mason, A. J., Parrish, R. R. and Brewer, T. S. 2004. U-Pb geochronology of Lewisian orthogneiss in the Outer Hebrides, Scotland: implications for the tectonic setting and correlation of the South Harris Complex. Journal of the Geological Society of London, 161, 45-54

Okeke, P. O., Borley, G. D. and Watson, J. 1983. A geochemical study of Lewisian metasedimentary granulites and gneisses in the Scourie-Laxford area of northwest Scotland. Mineralogical Magazine, 47, 1-9.

Park, R. G. 1970. Observations on Lewisian chronology. Scottish Journal of Geology, 6, 379-399.

Park, R. G. 2005. The Lewisian terrane model: a review. Scottish Journal of Geology, 41, 105-118.

Park, R. G. and Cresswell, D. 1972. Basic dykes in the early Precambrian (Lewisian) of NW Scotland: their structural relations, conditions of emplacement and orogenic significance. Reports of the 24th International Geological Congress, Montreal, 1, 238-245.

Park, R. G., Stewart, A. D. and Wright, D. T. 2002. The Hebridean terrane. In: Trewin, N. H. (ed) The Geology of Scotland. The Geological Society, London, 45-80.

Park, R. G. and Tarney, J. 1987. The Lewisian complex: a typical Precambrian highgrade terrain? In: Park, R. G. and Tarney, J. (eds) Evolution of the Lewisian and Comparable Precambrian High Grade Terrains, Geological Society of London Special Publication, 27, 13-26.

Peach, B. N., Horne, J., Gunn, W., Clough, C. T., Hinxman, L. W. and Cadell, H. M. 1892. Geological Survey of Scotland Sheet 107, Lochinver. Ordnance Survey, Southampton.

Peach, B. N., Horne, J., Gunn, W., Clough, C. T., Hinxman, L. W. and Teall, J. J. H. 1907. The geological structure of the North-West Highlands of Scotland. Memoir of the Geological Survey of Great Britain. HMSO, Glasgow.

Pride, C. and Muecke, G. K. 1980. Rare Earth Element Geochemistry of the Scourian Complex NW Scotland - Evidence for the Granite - Granulite Link. Contributions to Mineralogy and Petrology, 73, 403-412.

Ramsay, J. G. and Graham, R. H. 1970. Strain variation in shear belts. Canadian Journal of Earth Sciences, 7, 786-813.

Rollinson, H. and Tarney, J. 2005. Adakites - the key to understanding LILE depletion in granulites. Lithos, 79, 61-81

Rollinson, K. R. 1996. Tonalite-trondhjemite-granodiorite magmatism and the genesis of Lewisian crust during the Archaean. In: Brewer, T. S. (ed.) Precambrian Crustal Evolution in the North Atlantic Region, Geological Society of London Special Publication, 112, 25-42.

Rollinson, H. R. 1994. Origin of felsic sheets in the Scourian granulites: new evidence from rare earth elements. Scottish Journal of Geology, 30, 121-129.

Sheraton, J. W., Skinner, A. C. and Tarney, J. 1973. The geochemistry of the Scourian gneisses of the Assynt district. In: Park, R. G. and Tarney, J. (eds) The early Precambrian of Scotland and related rocks of Greenland, University of Keele, Keele, 31-43.

Sutton, J. and Watson, J. V. 1951. The pre-Torridonian metamorphic history of the Loch Torridon and Scourie areas in the northwest Highlands, and its bearing on the chronological classification of the Lewisian. Quarterly Journal of the Geological Society of London, 106, 241-307.

Sutton, J. and Watson, J. V. 1962. Further observations on the margin of the 
831

832

833

834

835

836

837

838

839

840

841

842

843

844

845

846

847

848

849

850

851

852

853

854

855

856

857

858

859

860

861

862

863

864

865

866
Laxfordian complex of the Lewisian near Loch Laxford, Sutherland.

Transactions of the Royal Society of Edinburgh, 65, 89-106.

Tarney, J. and Weaver, B. L. 1987. Mineralogy, petrology and geochemistry of the Scourie dykes: petrogenesis and crystallisation processes in dykes intruded at depth. In: Park, R. G. and Tarney, J. (eds) Evolution of the Lewisian and comparable Precambrian high grade Terrains, Geological Society of London Special Publication, 27, 217-233.

Taylor, P.N., Jones, N.W., and Moorbath, S. 1984. Isotopic assessment of relative contributions from crust and mantle sources to the magma genesis of Precambrian granitoid rocks. Philosophical Transactions of the Royal Society of London, A 310, 605-625.

Waters, F. G., Cohen, A. S., O'Nions, R. K. and O'Hara, M. J. 1990. Development of Archaean lithosphere deduced from chronology and isotope chemistry of Scourie Dykes. Earth and Planetary Science Letters, 97, 241-255.

Watkins, J.M., Clemens, J.D., and Treloar, P.J. 2007. Archaean TTGs as sources of younger granitic magmas: melting of sodic metatonalites at 0.6-1.2 GPa. Contributions to Mineralogy and Petrology, 154, 91-110.

Weaver, B. L. and Tarney, J. 1981a. Lewisian gneiss geochemistry and Archaean crustal development models. Earth and Planetary Science Letters, 55, 171180.

Weaver, B. L. and Tarney, J. 1981b. The Scourie Dyke Suite: Petrogenesis and Geochemical Nature of the Proterozoic Sub-Continental Mantle. Contributions to Mineralogy and Petrology, 78, 175-188.

Wheeler, J. (2009). Reference in this volume.

Whitehouse, M. J. 1989. Sm-Nd evidence for diachronous crustal accretion in the Lewisian complex of northwest Scotland. Tectonophysics, 161, 245-256.

Whitehouse, M.J. and Bridgwater, D. 2001. Geochronological constraints on Palaeoproterozoic crustal evolution and regional correlations of the northern Outer Hebridean Lewisian Complex, Scotland. Precambrian Research, 105, 227-245.

Wilks, K. R. and Carter, N. L. 1990. Rheology of some continental lower crustal rocks. Tectonophysics, 182, 57-77.

Zhu, X.K., O’Nions, R.K., Belshaw, N.S. and Gibb, A. J. 1997. Lewisian crustal history from in situ SIMS mineral chronometry and related metamorphic textures. Chemical Geology, 136, 205-218. 
Figure captions

868 Figure 1: Simplified geological map of the North-west Highlands, showing the outcrop of the Lewisian Gneiss Complex and the position of the Laxford Shear Zone.

Figure 2(a): Simplified geological map of the area around the Laxford Shear Zone, based on recent BGS mapping and the $19^{\text {th }}$ century BGS survey (Peach et al., 1892). Ticks indicate British National Grid.

Figure 2(b): The zones identified by Sutton and Watson (1951), superimposed upon the map as in Figure 2a. 1 indicates the 'local Laxfordian Front' of Sutton and Watson (1951); 2 indicates the Ben Stack Line of Lambert and Holland (1972).

Figure 3: Sketch cross-section through the Laxford Shear Zone, modified after Beach et al. (1974). Not to scale.

Figure 4: Interpretation of the Laxfordian structures across the Laxford front in terms of a gently southward-inclined shear zone with a top to the north sense of shear (after Coward, 1974).

Figure 5: Photo of pink Laxfordian granite sheet cutting gneisses with a strong Inverian foliation in the central part of the Laxford Shear Zone [NC 1637 4941]. Field of view c. $5 \mathrm{~m}$ across. BGS photo P593114, (C) NERC.

Figure 6: Photo of pink Laxfordian granite sheets cutting tonalitic gneisses with mafic and ultramafic lenses, in the northern part of the Laxford Shear Zone [NC 172 507]. Graham Park for scale. Photo (C) John Myers.

Figure 7: Primitive mantle-normalised trace-element plot for Scourie Dykes north and south of the Laxford Shear Zone. Data for all groups of Scourie Dykes from Assynt from Weaver and Tarney (1981b). Data for Rhiconich Scourie Dykes from Table 1.

Table 1: Major and trace element data for Scourie Dykes from the Rhiconich terrane. Analyses were carried out by XRF, using the PW2400 spectrometer and standard procedures employed by the UKAS-accredited analytical labs at BGS Keyworth.

897

898

899

900 


$\begin{array}{rlrrrrrrr}\text { Sample } & & \text { KG 099 } & \text { KG 101 } & \text { KG 103 } & \text { KG 104 } & \text { KG 105 } & \text { KG 106 } & \text { KG 107 } \\ \text { Grid reference } & & \text { NC 227 477 } & \text { NC 230 482 } & \text { NC 233 486 } & \text { NC 269 529 } & \text { NC 273 527 } & \text { NC 273 527 } & \text { NC 282 448 } \\ \mathrm{SiO} 2 & \mathrm{wt} \% & 56.80 & 46.72 & 45.95 & 50.47 & 50.22 & 49.30 & 51.04 \\ \mathrm{TiO} 2 & \mathrm{wt} \% & 0.71 & 2.27 & 1.20 & 0.79 & 1.28 & 1.56 & 0.79 \\ \mathrm{Al2O3} & \mathrm{wt} \% & 14.30 & 14.52 & 8.31 & 13.48 & 13.66 & 13.04 & 14.99 \\ \mathrm{Fe} 2 \mathrm{O} 3 \mathrm{t} & \mathrm{wt} \% & 9.86 & 16.06 & 14.96 & 12.19 & 12.81 & 13.96 & 11.29 \\ \mathrm{Mn} 3 \mathrm{O} 4 & \mathrm{wt} \% & 0.16 & 0.24 & 0.24 & 0.21 & 0.20 & 0.24 & 0.20 \\ \mathrm{MgO} & \mathrm{wt} \% & 5.27 & 5.40 & 15.30 & 7.10 & 7.06 & 6.34 & 7.24 \\ \mathrm{CaO} & \mathrm{wt} \% & 8.06 & 8.74 & 8.14 & 10.29 & 10.28 & 9.69 & 9.03 \\ \mathrm{Na} 2 \mathrm{O} & \mathrm{wt} \% & 3.54 & 2.87 & 1.20 & 2.71 & 2.56 & 2.68 & 3.00 \\ \mathrm{~K} 2 \mathrm{O} & \mathrm{wt} \% & 0.92 & 1.64 & 2.20 & 1.18 & 0.63 & 1.46 & 1.46 \\ \mathrm{P} 2 \mathrm{O} 5 & \mathrm{wt} \% & 0.12 & 0.34 & 0.11 & 0.07 & 0.09 & 0.11 & 0.09 \\ \mathrm{LOI} & \mathrm{wt} \% & 0.71 & 0.80 & 1.72 & 1.09 & 0.87 & 0.96 & 1.27 \\ \mathrm{Total} & \mathrm{wt} \% & 100.53 & 99.95 & 100.00 & 99.68 & 99.74 & 99.44 & 100.50 \\ & & & & & & & & \\ \mathrm{Sc} & \mathrm{ppm} & 27 & 35 & 23 & 46 & 36 & 37 & 31 \\ \mathrm{~V} & \mathrm{ppm} & 183 & 310 & 273 & 301 & 330 & 365 & 229 \\ \mathrm{Cr} & \mathrm{ppm} & 177 & 155 & >1000 & 125 & 210 & 132 & 114 \\ \mathrm{Co} & \mathrm{ppm} & 36 & 44 & 89 & 45 & 47 & 45 & 38 \\ \mathrm{Ni} & \mathrm{ppm} & 49 & 66 & 919 & 77 & 124 & 105 & 121 \\ \mathrm{Cu} & \mathrm{ppm} & 6 & 76 & 116 & 103 & 74 & 36 & 9 \\ \mathrm{Zn} & \mathrm{ppm} & 69 & 149 & 137 & 92 & 104 & 160 & 102 \\ \mathrm{Ga} & \mathrm{ppm} & 17 & 22 & 18 & 15 & 18 & 20 & 21 \\ \mathrm{Rb} & \mathrm{ppm} & 9 & 59 & 110 & 35 & 13 & 20 & 37 \\ \mathrm{Sr} & \mathrm{ppm} & 409 & 263 & 49 & 201 & 200 & 213 & 256 \\ \mathrm{Y} & \mathrm{ppm} & 16 & 42 & 13 & 20 & 19 & 25 & 16 \\ \mathrm{Zr} & \mathrm{ppm} & 95 & 180 & 76 & 42 & 67 & 85 & 67 \\ \mathrm{Nb} & \mathrm{ppm} & 5 & 12 & 3 & 3 & 4 & 5 & 4 \\ \mathrm{Ba} & \mathrm{ppm} & 120 & 506 & 343 & 246 & 139 & 199 & 186 \\ \mathrm{La} & \mathrm{ppm} & 19 & 24 & 11 & <6 & 10 & 9 & 12 \\ \mathrm{Ce} & \mathrm{ppm} & 40 & 57 & 20 & 9 & 13 & 21 & 23 \\ \mathrm{Nd} & \mathrm{ppm} & 19 & 30 & 15 & 5 & 8 & 11 & 11 \\ \mathrm{Sm} & \mathrm{ppm} & 2 & 4 & 6 & <2 & 4 & 3 & 2 \\ \mathrm{Yb} & \mathrm{ppm} & 1 & 6 & <1 & 3 & 3 & 2 & 3 \\ \mathrm{Hf} & \mathrm{ppm} & 1 & 3 & 2 & <1 & 3 & 4 & 1 \\ & & & & & & & & \end{array}$




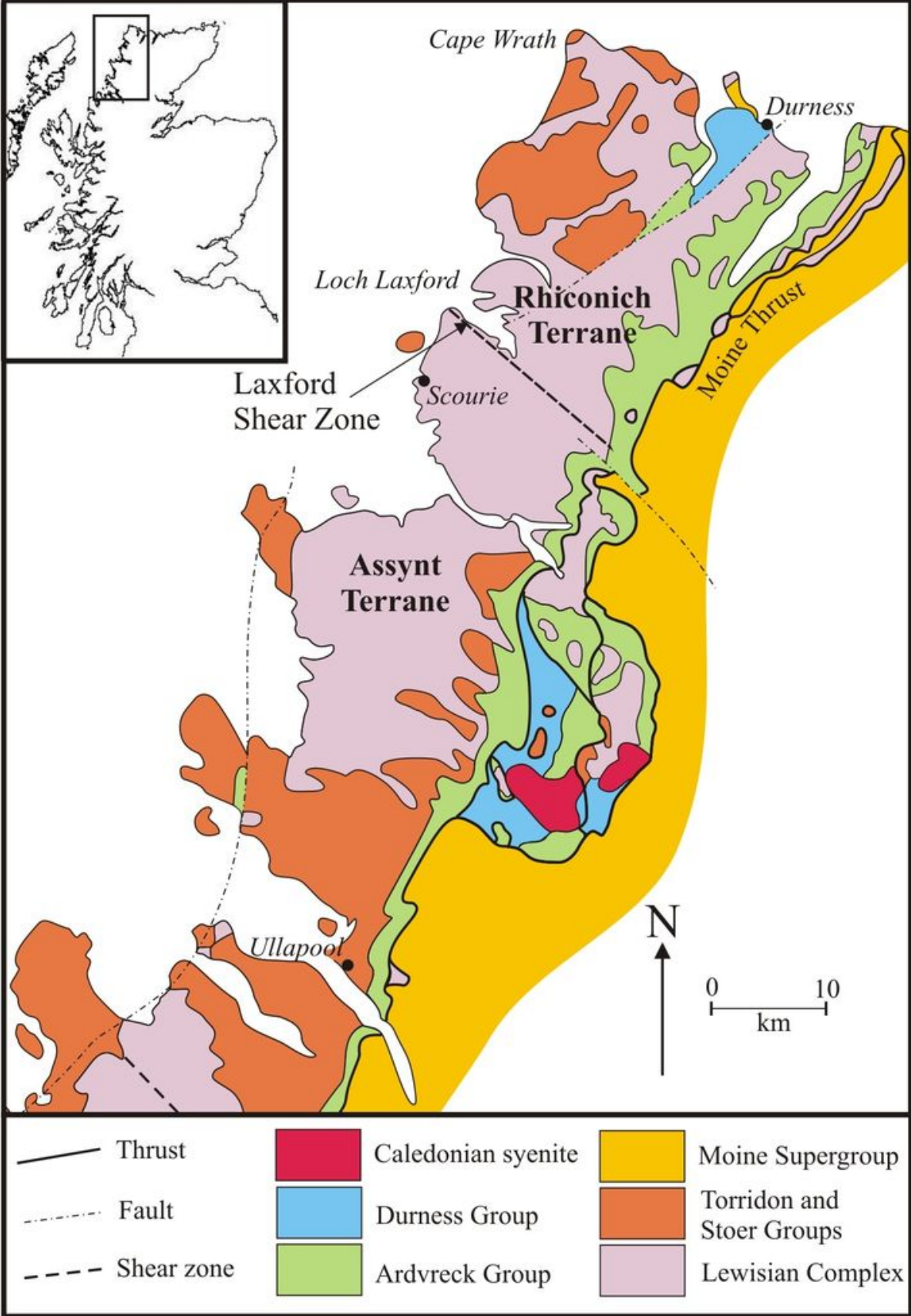




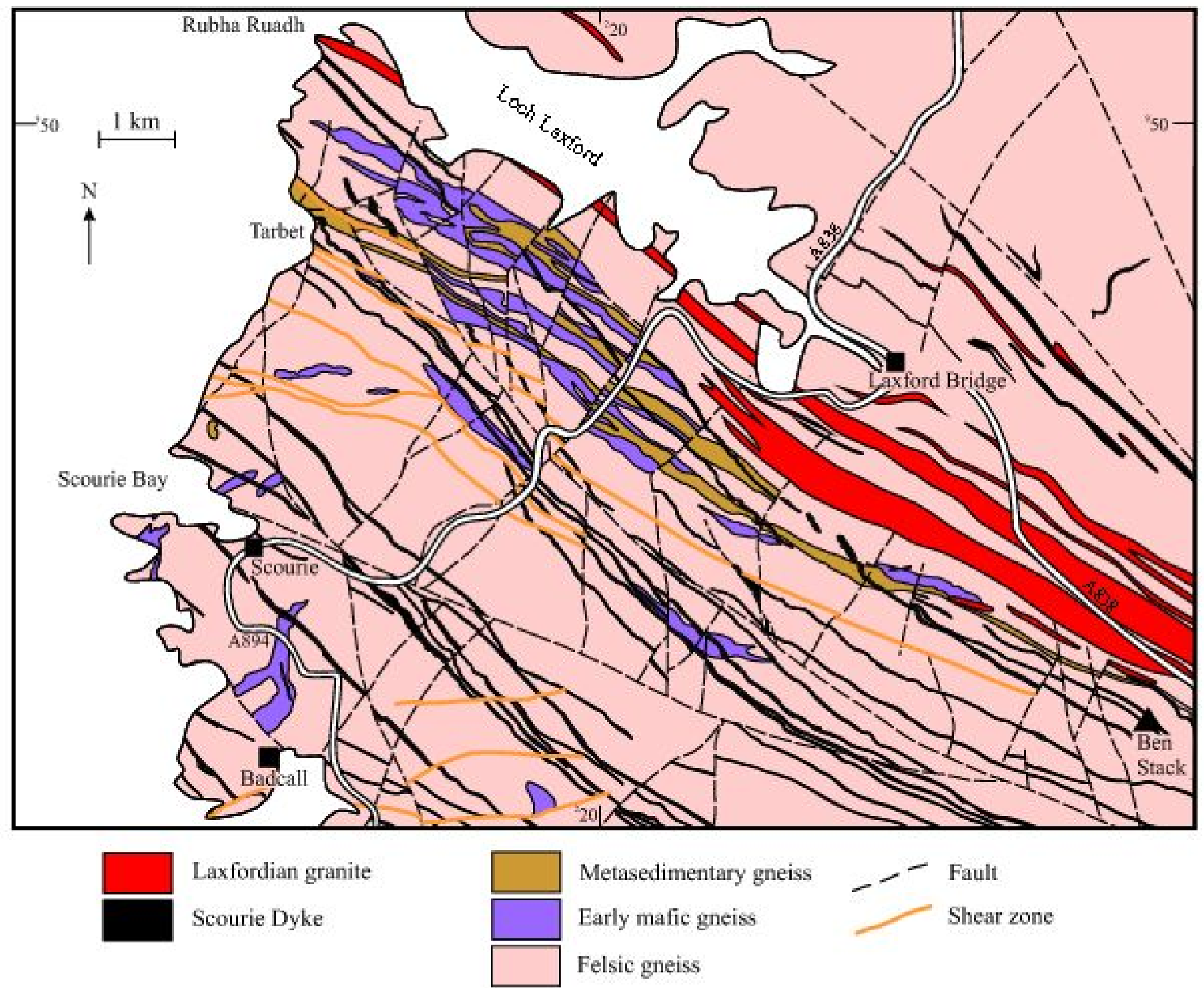



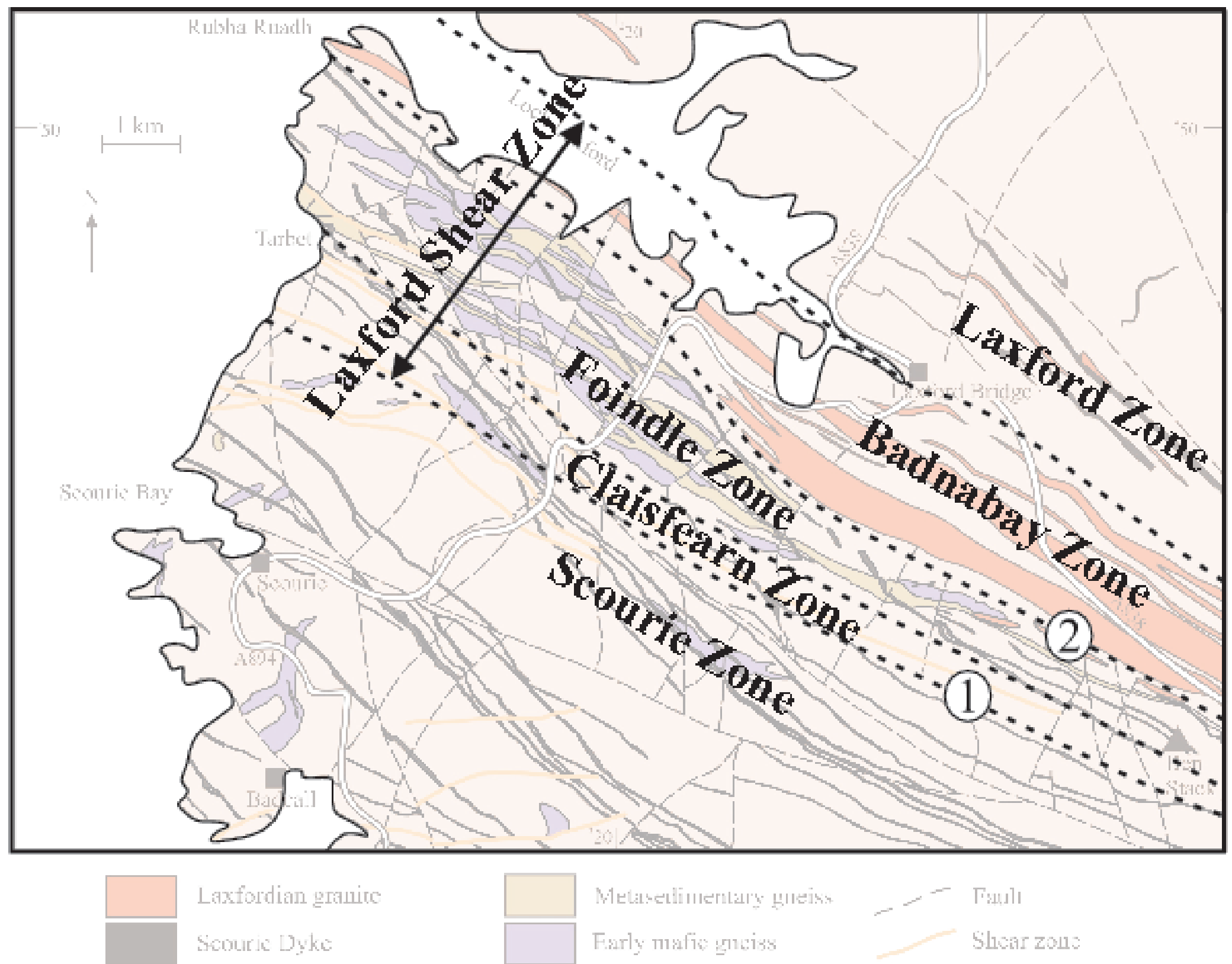

Laxfordian erauic

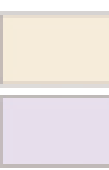

Metaseringratay gueiso

Fintul|

Scouris Dyke 
Scourie Dykes deformed by Laxfordian folds cut by Scourie Dykes
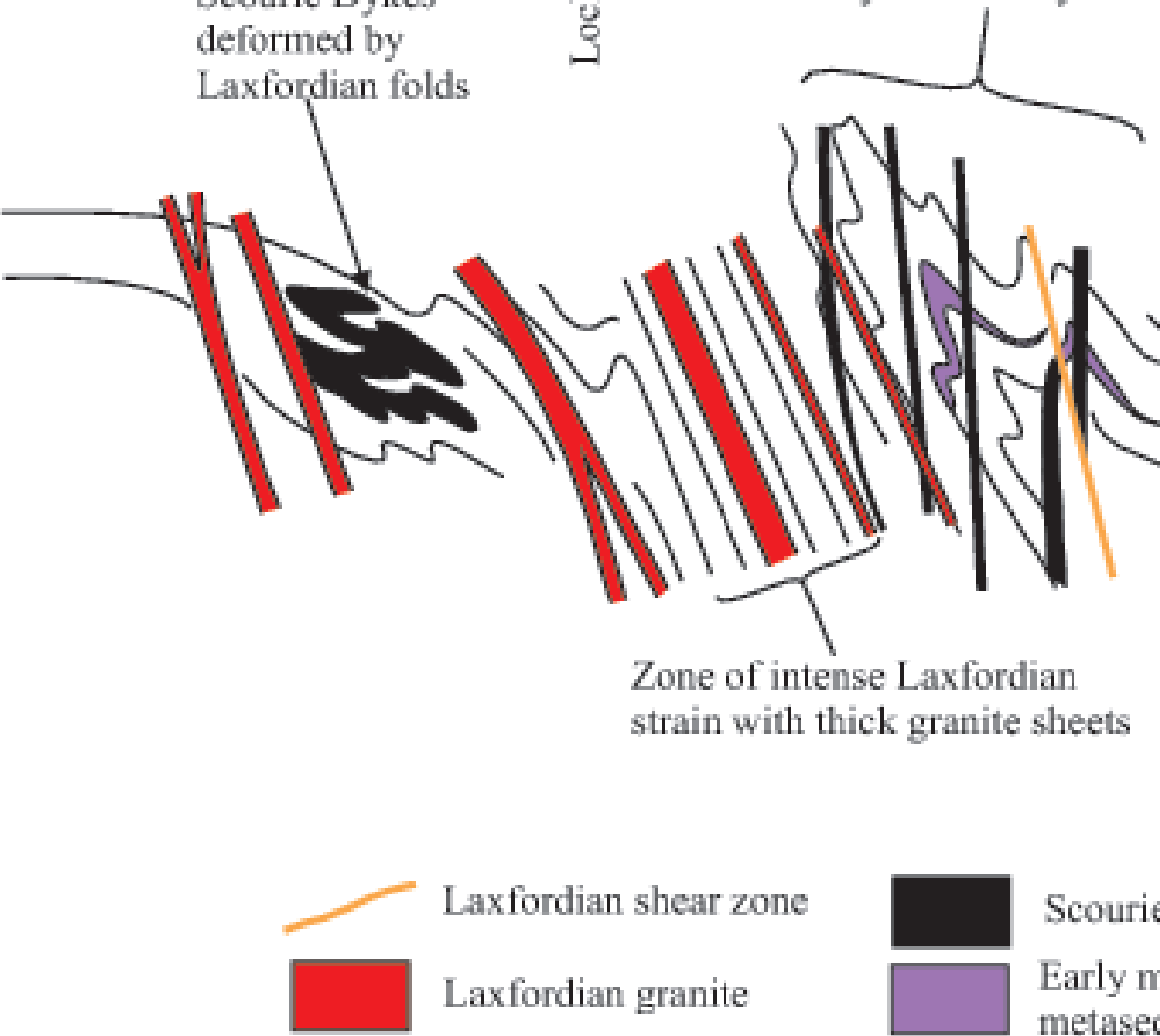


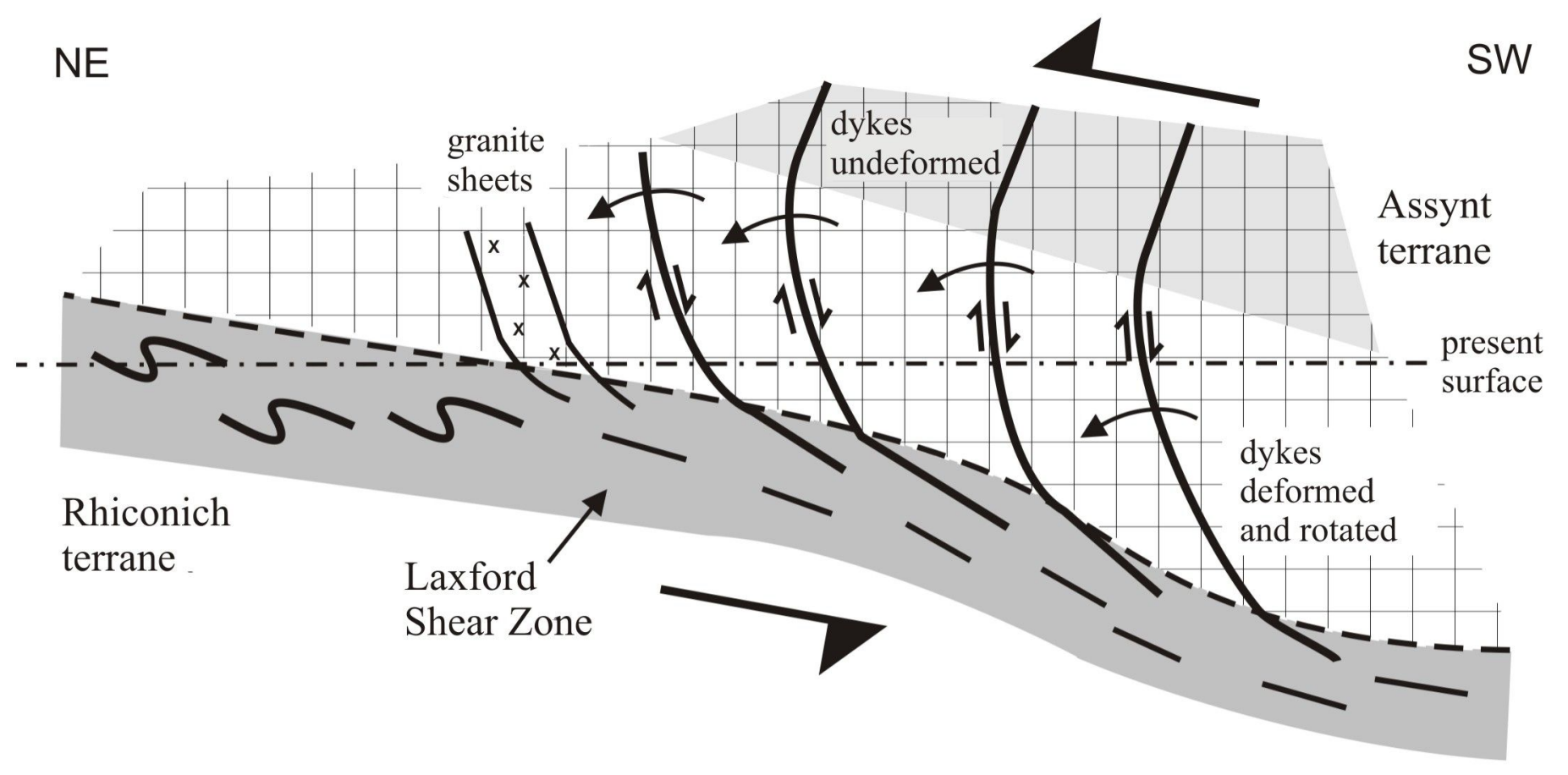




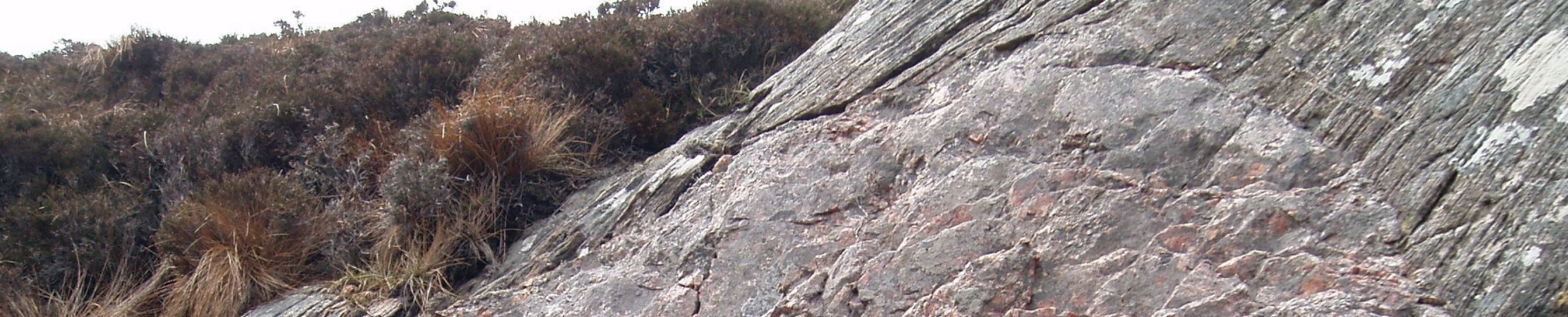

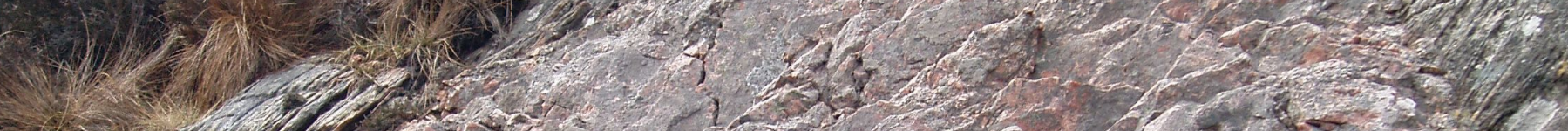
6in

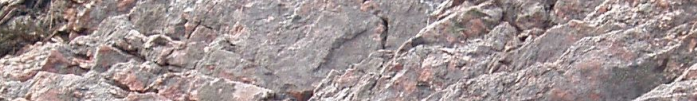

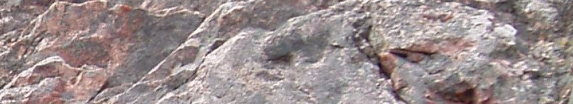
(2)

-1. 1.

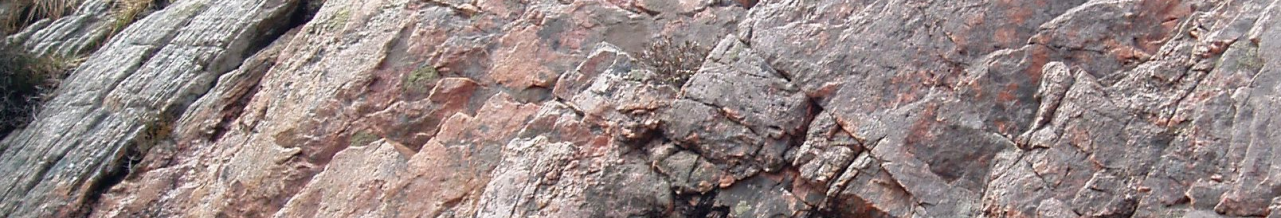

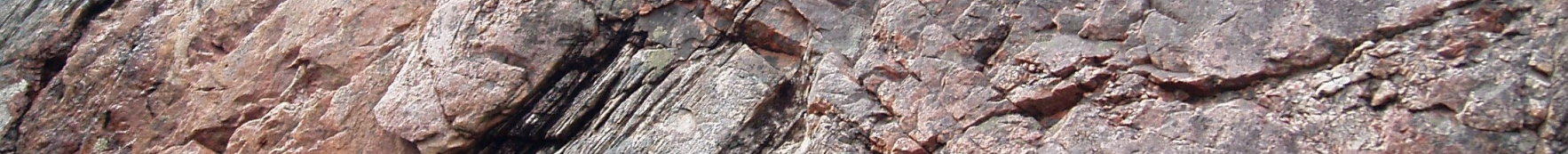
ret.

1.
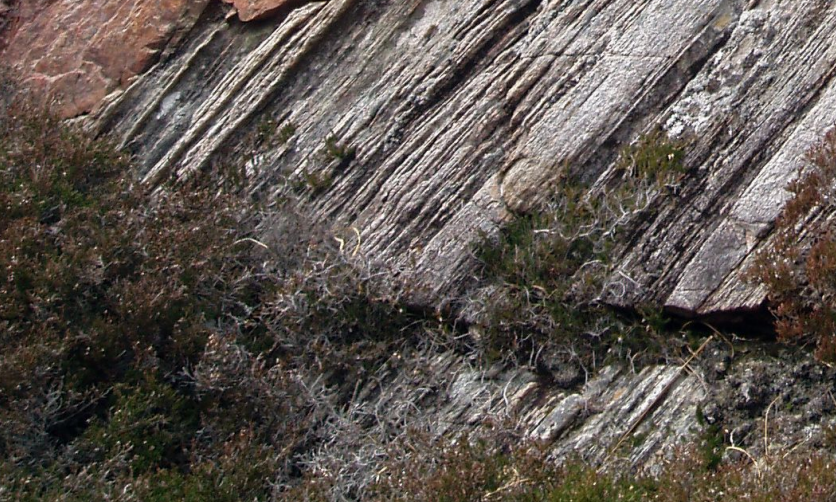

1. 190
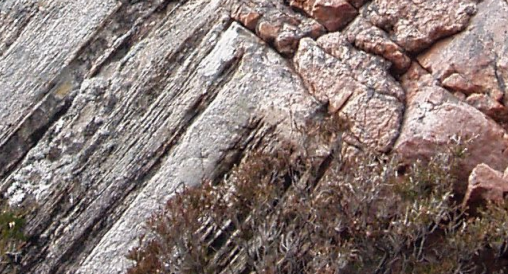

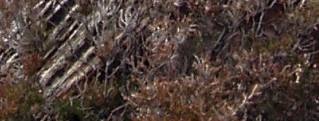

$x^{2}$

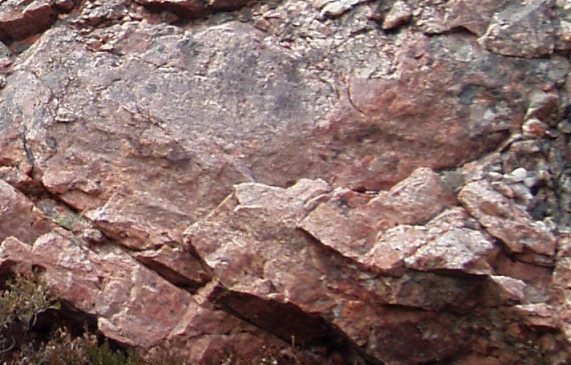

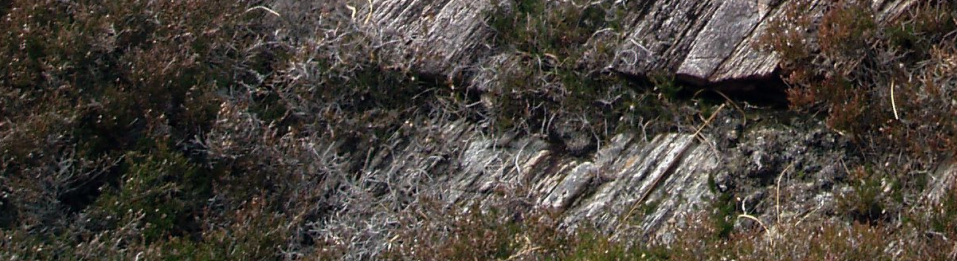
St (2) ancot

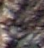

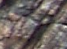
. (a)

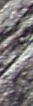

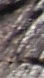


